\title{
Valentino's Syndrome in a Child: Perforated Peptic Ulcer Mimicking Acute Appendicitis
}

\author{
Çocukta Valentino Sendromu: Akut Apandisiti Taklit Eden Perfore \\ Peptic Ülser
}

\author{
Zeliha AKIŞ YILDIZ, Hayriye Nihan AYYILDIZ
}

Health Sciences University, Umraniye Training and Research Hospital, Pediatric Surgery Clinic, İstanbul, Turkey

\begin{abstract}
The most common cause of acute abdomen in children is appendicitis. However, in cases when the appendix is observed normally during surgery, other surgical causes should be considered. Rarely, in the differential diagnosis of right lower quadrant (RLQ) pain, gastric or duodenal ulcer perforation, defined as Valentino Syndrome, should be considered and evaluated for possible pathology. In this case report, we aimed to discuss a case of unusual gastric perforation that presented with symptoms and signs suggestive of appendicitis. Free air was not identified on plain abdominal x-ray, and also no specific finding was found on ultrasonography. The appendix was normal during surgery. There was plenty of serous fluid in the right lower quadrant. When fibrin was observed in upper quadrants, the incision was expanded and it turned out to be a gastric perforation and was repaired. In cases with peritonitis findings in the examination of the abdomen, even though the appendix is normal, it is very important to evaluate all intraabdominal organs in terms of other diagnoses.
\end{abstract}

Key Words: Gastric perforation, Pediatric acute abdomen, Valentino's Syndrome

öz

Çocuklarda en sık akut karın nedeni apandisittir. Ancak ameliyatta appendiksin normal izlendiği durumlarda diğer cerrahi sebepler gözden geçirilmelidir. Sağ alt kadran karın ağrısının ayıııc tanısında nadir de olsa Valentino Sendromu olarak tanımlanmış gastrik ya da duodenal ülser perforasyonu akla gelmeli ve olası patoloji yönünden değerlendirilmelidir. Bu olgu sunumunda, bulguları apandisiti düşündüren alışılmadık mide perforasyonu olan bir olgumuzu tartışmayı amaçladık. Olgunun ayakta direkt karın grafisinde serbest hava izlenmediği gibi ultrasonografide de spesifik bulgu saptanmamıştı. Operasyonda apendiksin normal olduğu gözlendi. Sağ alt kadranda bol miktarda seröz sıvı mevcuttu. Üst kadranlarda fibrin izlenmesi üzerine insizyon genişletildiğinde mide perforasyonu olduğu görülerek onarıldı. Batın muayenesinde peritonit bulguları olan olgularda, apendiks normal olsa da mutlaka diğer tanılar açısından karın içi tüm organların değerlendirilmesi önem arz etmektedir.

Anahtar Sözcükler: Mide perforasyonu, Çocuklarda akut karın, Valentino sendromu

\section{INTRODUCTION}

Appendicitis is the most common cause of RLQ (right lower quadrant) pain in adolescents and young adults. Common and uncommon pathologies may mimic acute appendicitis and present as a diagnostic challenge for the clinician. In childhood, the differential diagnosis of acute abdomen includes many pathologies such as non-specific mesenteric lymphadenitis, pyelonephritis, acute gastroenteritis, urinary tract infection, diverticulitis and perforated peptic ulcer $(1,2)$.

\section{CASE PRESENTATION}

A 17-year-old boy presented with abdominal pain. The physical examination revealed normal vital signs, guarding and tenderness in the right lower quadrant. White blood cell count was elevated $\left(21.10010^{9} \mathrm{cell} / \mathrm{S} / \mathrm{L}\right)$ and $\mathrm{C}$ reactive protein was under $1 \mathrm{mg} / \mathrm{dl}$. Urinalysis was normal. An upright abdominal X-ray (Figure 1) showed a normal intestinal gas pattern without pneumoperitoneum. On ultrasonographic examination, the appendix could not be visualized, and there was some free fluid in the right iliac fossa. No other abnormality was noted. The patient proceeded to an operation with the initial diagnosis of appendicitis. At laparotomy, visualization of appendix was 


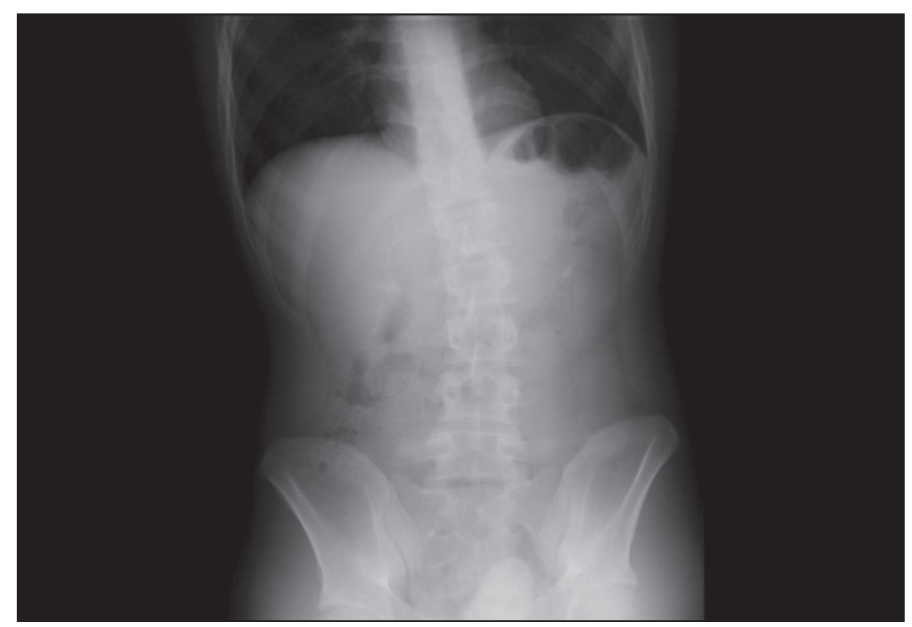

Figure 1: The patient's upright abdominal X-ray.

normal and we ruled out the presence of Meckel diverticulum. Pus was observed in upper quadrants and we decided to explore the upper quadrants of the abdomen. At exploration, a perforation area was identified on the anterior side of stomach and primary repair with pedicled omental patch performed. The patient was discharged uneventfully on postoperative day 5 .

\section{DISCUSSION}

Valentino's syndrome was described in 1926 when a famous American film actor Rudolph Valentino died due to perforated peptic ulcer. He presented with the signs and symptoms of acute appendicitis to a hospital in New York City. He was diagnosed with acute appendicitis and he had an appendectomy. Postoperatively, he died due to peritonitis and multiple organ system dysfunction. The cause of death was determined in autopsy that revealed a perforated gastric ulcer $(2,3)$.

Only a few cases of Valentino's syndrome have been reported in childhood and most of them were due to duodenal perforation $(2,4-6)$. In our case, gastric ulcer perforation was the main pathology. After identification of gastric perforation, primary suture repair was performed with an omental patch. The case had an unusual presentation without any previous history of peptic ulcer disease. On imaging studies, no specific pathology was identified. During surgery, initial evaluation of appendix and Meckel diverticulum which are the frequent causes of abdominal pain is essential. When no pathology was detected in these regions, other surgical causes should be excluded. If the disorder not recognized during surgery, it can cause serious morbidity and mortality (2).

Localized pain in the RLQ can mimic acute appendicitis. Initial imaging may demonstrate some fluid with a normal appendix on ultrasound or may not specify a specific cause. Although imaging methods do not indicate a specific pathology, the surgeon's suspicion should be guiding.

\section{CONCLUSION}

Evaluation of a child with acute abdominal pain is sometimes difficult. Identification of a normal appendix can be more problematic, because various pathologies may mimic acute appendicitis. Perforation of gastric or duodenal ulcer, also known as Valentino's syndrome, should be considered as a rare cause of acute abdominal pain in the differential diagnosis.

\section{REFERENCES}

1. Yu J, Fulcher AS, Turner MA, Halvorsen RA. Helical CT evaluation of acute right lower quadrant pain: part I, common mimics of appendicitis. AJR Am J Roentgenol 2005;184: 1136-42.

2. Wijegoonewaredene SI, Stein J, Cooke D, Tien A. Valentino's syndrome a perforated peptic ulcer mimicking acute appendicitis. BMJ Case Rep 2012; 2012.

3. Valentino loses battle with death: Greatest of screen lovers fought valiantly for life. Plattsburgh Sentinel 1926;1.

4. Ramírez-Ramírez MM, Villanueva-Saenz E. Valentino's syndrome. Perforated peptic ulcer with unusual clinical presentation. Rev Gastroenterol Mex 2016;81:225-6.

5. Hussain K, Munir A, Wahla MS, Masood J. Valentino's syndrome: Perforated peptic ulcer mimicking acute appendicitis managed through rutherford morrison incision. J Coll Physicians Surg Pak 2016;26:727-8.

6. Amann C, Austin A, Rudinsky S. Valentino's syndrome: A lifethreatening mimic of acute appendicitis. Clin Pract Cases Emerg Med 2016;1: 44-6. 